\title{
Pemodelan Arus Arcing Tegangan Rendah pada Kabel Fleksibel (Serabut) menggunakan Elman Neural Network
}

\author{
Liga Primabaraka, Dimas Anton Asfani, dan I Made Yulistya Negara \\ Jurusan Teknik Elektro, Fakultas Teknologi Industri, Institut Teknologi Sepuluh Nopember (ITS) \\ Jl. Arief Rahman Hakim, Surabaya 60111 Indonesia \\ e-mail: liga.primabaraka12@mhs.ee.its.ac.id, anton@ee.its.ac.id, yulistya@ee.its.ac.id
}

\begin{abstract}
Abstrak-Penggunaan listrik dapat menyebabkan bahaya jika tidak diperlakukan dengan baik. Salah satu bahaya yang dapat terjadi adalah kebakaran akibat dari adanya arc flash yang berasal dari peristiwa hubung singkat. Maka dari itu, diperlukan sebuah analisa bahaya listrik pada tegangan rendah sehingga keamanan pada sisi pelanggan dapat tetap terjaga. Arus Arc flash pada tegangan rendah memiliki karakteristik berupa bentuk gelombang yang nilainya tinggi, namun durasi yang relative singkat. Hal ini berakibat pada tidak bereaksinya alat pengaman dalam mengatasi gangguan ini. Dalam tugas akhir ini, penulis akan membuat sebuah pemodelan terhadap arus arcing pada tegangan rendah. Tujuan dari melakukan pemodelan adalah untuk memudahkan analisa terhadap fenomena arc flash pada tegangan rendah sehingga nantinya ditemukan solusi untuk mengatasi bahaya yang dapat diakibatkan oleh fenomena arc flash itu sendiri. Pemodelan ini menggunakan metode Elman Neural Network yang berfungsi untuk membentuk karakteristik dari bentuk arus arc flash dengan menentukan nilai hambatan pada tempat terjadinya arcing. Pemodelan dilakukan berdasarkan kasus arc flash pada kabel fleksibel dengan jumlah serabut yang berbeda-beda. Keluaran dari tugas akhir ini adalah sebuah arus arcing pemodelan yang bentuknya mirip dengan arus arcing hasil percobaan. Hasil yang didapatkan adalah arus arcing pemodelan memiliki bentuk yang mirip dengan arus arcing percobaan.
\end{abstract}

Kata Kunci-arc flash, elman neural network, kabel fleksibel, pemodelan, tegangan rendah

\section{PENDAHULUAN}

$\mathrm{D}$ I era modern ini, listrik menjadi kebutuhan yang sangat vital. Dalam beberapa tahun terakhir rasio elektrifikasi mengalami peningkatan. Dengan banyaknya pelanggan listrik skala rumah tangga, keamanan instalasi listrik tegangan rendah menjadi hal yang sangat penting untuk diperhatikan. Salah satu bahaya yang dapat terjadi yang diakibatkan oleh listrik adalah kebakaran. Arus hubung singkat dapat menimbulkan arc flash (busur api) yang dapat memacu terjadinya kebakaran. Arcing pada tegangan rendah memiliki nilai yang cukup tinggi, namun memiliki durasi yang cenderung singkat sehingga tidak dapat dideteksi oleh perangkat pengaman seperti fuse maupun circuit breaker. Analisa mengenai arcing sangat perlu dilakukan agar dapat menghindari bahaya yang mungkin dapat diakibatkan oleh fenomena tersebut. Bahaya yang mungkin dapat ditimbulkan adalah electric shock, arc flash burn, arc flash blast, intense light, sound wave, projectiles [1]. Dalam rangka memudahkan analisa dari arcing tegangan rendah maka diperlukan sebuah pemodelan dari arus arcing. Tujuan dari melakukan pemodelan adalah dari faktor kemudahan agar ketika hendak melakukan analisa arcing tidak perlu melakukan pengambilan data karena bentuk gelombangnya sudah dimodelkan. Artificial Neural Network (ANN) atau Jaringan Saraf Tiruan (JST) telah banyak diterapkan di berbagai permasalahan, seperti lalu lintas, komunikasi, dan rekayasa transportasi. Oleh karena itu, disini kami hendak memanfaatkan JST dalam melakukan pemodelan arus arcing. Maka dari itu, penulis hendak melakukan penelitian yang berjudul "Pemodelan Arus Arcing Tegangan Rendah pada Kabel Fleksibel (Serabut) menggunakan Elman Neural Network" dimana pemodelan ini akan menggunakan JST yang membentuk karakteristik dari gelombang arc flash dan memanfaatkan parameter parameter lainnya, seperti energi, jumlah serabut, dan waktu.

\section{DASAR TEORI}

\section{A. Pemodelan Arus Arcing Tegangan Rendah}

Arcing adalah sebuah peluahan elektrik yang mengalir diantara dua elektroda melalui gas atau uap air [2]. Arc Flash dapat terjadi akibat adanya hubung singkat. Hubung singkat dapat terjadi karena kontak langsung kedua konduktor yang berbeda potensial memiliki isolasi yang tidak standar, sehingga bagian dalam kabel saling bersentuhan.

Arc memiliki tiga wilayah umum: katoda, anoda, dan kolom positif. Drop tegangan didalam katoda ada di sekitar $20 \mathrm{~V}$ atau kurang [3]. Drop tegangan dalam wilayah anoda biasanya jauh lebih kecil. Kolom positif, atau plasma, memiliki gradient tegangan yang cukup seragam [4].

Beberapa karakteristik umum arus busur api listrik pada beban resistif yang telah diidentifikasi antara lain di setiap setengah cycle, arus memiliki dua nilai yaitu tidak bernilai (seolah-olah bernilai nol) dan bernilai, begitu seterusnya setiap setengah cycle . Laju kenaikan dan maksimum (max) arus biasanya selalu lebih besar dibanding arus beban normal. 
Busur api listrik bukanlah fenomena dengan bentuk gelombang stasioner, segmen arusnya dapat berdampingan dengan segmen aliran arus normal. Muncul noise frekuensi tinggi pada arus busur api listrik (dari $10 \mathrm{kHz}$ sampai dengan $1 \mathrm{GHz}$ ) [5]

Arc $120 \mathrm{~V}$ dan $240 \mathrm{~V}$ tidak dapat mempertahankan dirinya sendiri dan dapat padam dengan sangat cepat. Hal ini sangat meminimalisir insiden energi dan efeknya. [6]

Recurrent Neural Network (RNN) adalah sebuah jaringan yang mengakomodasi output jaringan untuk menjadi input jaringan yang kemudian digunakan untuk memproduksi output baru [7]. Arsitektur NN seluruhnya terinterkoneksi dengan network yang terhubung sebagian, termasuk jaringan multilayer feed forward dengan layer input dan output yang berbeda.

Elman RNN adalah jaringan recurrent sederhana. Ini adalah jaringan recurrent sebagian, yang mayoritas koneksinya adalah feedforward saja. Sebuah kelompok unit spesifik menerima sinyal feedback dari time step sebelumnya. Unit ini dikenal dengan nama context unit [8]. Dengan demikian, input layer terdiri dari dua bagian, unit input sebenarnya dan context unit. Context unit adalah salinan dari aktivasi hidden unit. Elman RNN akan digunakan dalam menentukan nilai hambatan arcing. Train pada Elman RNN didasarkan dari data percobaan.

Di tahun 1941, schurig memaparkan bahwa tegangan arc biasanya memiliki puncak yang datar dan besar arus arcingfault berada diantara $57 \%$ sampai $100 \%$ dari arus hubung singkat [9]. Meskipun nilai pastinya masih diperdebatkan, besar dari arus arc adalah variable. Nilainya tergantung dari banyak faktor, termasuk impedansi dari ground path.

Pada Tahun 2015, Sanjaya membuat pemodelan busur api listrik tegangan rendah dengan beban resistif. Pemodelan ini menggunakan program Simulink dan menggunakan neural network dengan metode feed forward backpropagation [10]. Pemodelan yang dilakukan oleh Sanjaya menjadi acuan utama dalam pembuatan pemodelan ini.

\section{METODE PENELITIAN}

\section{A. Perancangan Alat Eksperimen}

Dalam tugas akhir ini, peristiwa arc flash tegangan rendah dibuat dengan menggunakan eksperimen di laboratorium. Penelitian ini diawali dengan perancangan alat eksperimen. Alat tersebut merupakan representasi sebuah instalasi listrik sederhana dengan menggunakan sumber listrik PLN, sebuah fuse, beban lampu bohlam sebanyak 10 buah, dua buah current transformator, sebuah verivolt dan dua kabel yang dipasang paralel dengan sistem yang serabutnya terbuka.

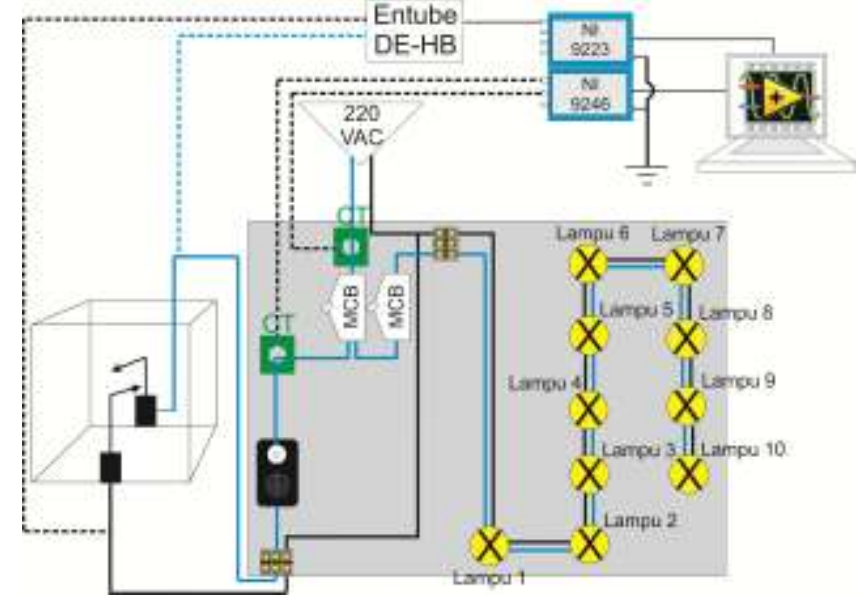

Gambar 2. Skema Alat Eksperimen Busur Api

Adapun komponen yamg berada pada skema alat eksperimen tersebut dimulai dari Sumber Tegangan. Sumber dari alat percobaan dalam penelitian ini berasal dari PLN 1 fasa dengan $\mathrm{V}_{\mathrm{rms}} 220 \mathrm{~V}$ dan frekuensi $50 \mathrm{~Hz}$. Kemudian ada Kabel Fleksibel NYMHY. Kabel yang dimaksud disini adalah kabel yang terhubung paralel dengan sistem untuk kemudian mengalami kejadian hubung singkat. Kabel tersebut adalah kabel fleksibel $2 \times 2.5 \mathrm{~mm}^{2}$ sepanjang $17 \mathrm{~m}$. Fuse box digunakan sebagai pengaman pada paralel. Rating fuse tersebut sebesar 6A. hal ini dimaksudkan untuk menyimulasikan perumahan yang memiliki kapasitas daya 1300 VA sekaligus menguji apakah fuse dapat trip saat terjadi busur api. Pada penelitian kali ini menggunakan beban lampu bohlam dengan spesifikasi 220 VA 100 Watt sebanyak 10 buah yang dihubungkan secara paralel. Chamber terbuat dari bahan akrilik dengan ukuran 30 $\mathrm{cm}, 15 \mathrm{~cm}, 20 \mathrm{~cm}$ dengan ketebalan $0,2 \mathrm{~mm}$. Chamber ini digunakan untuk melindungi peneliti dari percikan api ketika terjadi busur api. Trafo arus digunakan untuk mengukur arus pada sumber dan pada kabel paralel tempat terjadi hubung singkat. Fungsi dari trafo arus adalah menurunkan nilai arus untuk keamanan alat. Adapun ratio dari CT yang digunakan adalah 200/5. NI 9246 dan NI 9223 adalah sebuah alat akuisisi data. Dalam penggunaannya, alat ini akan terhubung ke PC dan dikontrol menggunakan program Labview. NI 9246 adalah alat yang digunakan untuk mengukur arus, sedangkan NI 9223 adalah alat yang digunakan untuk mengukur tegangan. Verivolt Entube DE-HB merupakan sensor tegangan dengan masukan tegangan maksimal $2000 \mathrm{~V}$, dan tegangan output maksimal 10V. alat ini akan terhubung dengan NI 9223. Komputer digunakan untuk mengontrol proses akusisi data. Software yang digunakan adalah NI LabWiew kemudian data tersebut diolah menggunakan Diadem. 


\section{B. Pengambilan Data}

Setelah semua sudah terangkai dengan baik seperti layout pada gambar 3.1, proses pengambilan data pun dimulai. Pengambilan data dilakukan sebanyak 10 kali untuk masingmasing serabut dengan jumlah serabut 1,3,6,12, dan 24 .

\section{Pengolahan Data}

Setelah dilakukan akusisi data, maka proses selanjutnya adalah pengolahan dari data tersebut. beberapa parameter kemudian ditentukan untuk dapat merepresentasikan karakteristik fenomena dari busur api pada tegangan rendah. Adapun parameter yang pertama adalah energi. Energi adalah jumlah daya dalan satuan waktu. Dalam percobaan ini, energy digunakan untuk menentukan $\mathrm{R}$ arc. Energi yang diambil adalah energi di tempat terjadi arc.

Parameter yang kedua adalah hambatan arcing. Nilai hambatan yang dimaksud disini adalah resistansi pada tempat terjadinya busur api listrik, kita namakan dengan Rarc. Nilai dari $\mathrm{R}$ arc didapatkan dari perhitungan hambatan pada kabel paralel dikurangi hambatan kabel hitam dan kabel biru. $\mathrm{R}$ arc digunakan sebagai target pelatihan neural network

\section{Pembuatan Model}

Pemodelan dilakukan menggunakan software matlab. Rangkaian ini terdiri dari power supply, hambatan dalam, $\mathrm{R}$ kabel hitam dan biru, R arc, switch on, switch off, dan R beban.

Adapun perincian dari masing-masing komponen pemodelan adalah sebagai berikut:

\section{Blok Rangkaian Utama}

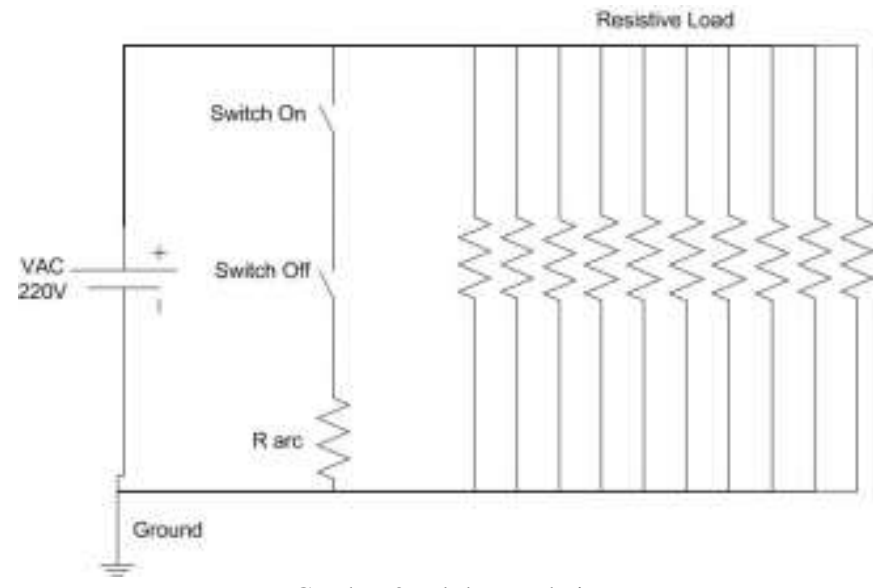

Gambar 3. Blok Rangkaian Utama

Adapun bagian-bagian dari blok ini dimulai dari Blok Power Supply. Blok power supply merupakan representasi dari sumber listrik PLN. Pada blok ini terdapat hambatan dalam yang nilainya diatur sedemikian rupa sehingga memiliki output pemodelan yang sesuai dengan output percobaan. Pada komponen sumber AC terdapat kolom bertuliskan peak amplitude. Karena sumber tegangan $220 \mathrm{~V}$, maka peak amplitude menjadi 200 VRMS $\times \sqrt{2}=311.13$ V. Beban dalam eksperimen ini adalah lampu bohlam sebanyak 10 buah dengan masing-masing memiliki daya $100 \mathrm{~W}$ att. Didalam pemodelan ini, beban direpresentasikan dengan sebuah resistor. Adapun nilai dari masing-masing beban adalah sebagai berikut $484 \Omega$. Berikutnya adalah Kabel hitam dan kabel biru yang saling terhubung seri dipasang secara paralel terhadap sumber. Kedua kabel ini adalah kabel fleksibel dengan panjang $17 \mathrm{~m}$. Nilai resistansi dari kedua kabel ini berdasarkan table yang sudah dijelaskan diatas

Terdapat dua sensor utama, yaitu sensor arus dan sensor tegangan. Sensor tegangan digunakan untuk mengukur tegangan yang diletakkan dekat dengan sumber. Adapun sens or arus digunakan untuk mengukur arus sumber dan arus arc. Tegangan sumber dan arus arc kemudian dihubungkan dengan time scope. Sedangkan arus sumber digunakan untuk menghitung energi sumber.

Kejadian hubung singkat yang mengakibatkan terjadinya busur api direpresentasikan dengan dua buah switch dan sebuah resistor variabel. Yang pertama adalah Rangkaian Switch On yang berfungsi untuk mengatur kapan hubung singkat mulai terjadi. Kemudian ada Rangkaian Switch Off yang berfungsi untuk mengatur kapan hubung singkat berakhir. Kemudian ada Rangkaian $\mathrm{R}$ arc yang mendapatkan input berasal dari blok neural network.

Kemudian ada rangkaian penghitung energy. Rangkaian ini berfungsi untuk menghitung energy total yang dimulai ketika terjadi hubung singkat. Blok ini mendapatkan masukan dari keluraran sensor arus arc dan sensor tegangan. Keluaran dari rangkaian ini dimasukkan ke output \& display dan JST.

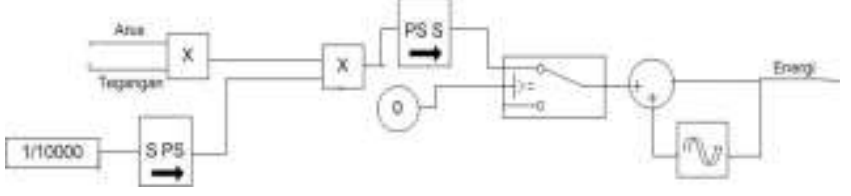

Gambar 4. Rangkaian Penghitung Energi

Pada gambar diatas, PS Product sebanyak dua buah. PS Product yang pertama berfungsi untuk mengalikan nilai Arus yang berasal dari Current sensor dengan Tegangan yang berasal dari Voltage Sensor. PS Product yang kedua terdapat dua input. Input yang pertama adalah hasil pengali dari PS Product yang sebelumnya, yakni VxI. Input yang kedua adalah reperesentasi dari $\Delta \mathrm{t}$ sebesar 1/10000. Output dari PS Product yang kedua adalah energi. Sum adalah komponen yang berfungsi untuk menjumlahkan dua input. Salah satu input adalah feedback dari output pada time step sebelumnya. Sedangkan delay berfungsi untuk memberikan jarak waktu untuk penjumlahan feedback sesuai dengan nilai $\Delta \mathrm{t}$, yakni sebesar 0.0001 s. Switch memiliki dua jenis input. Yakni control port dan input port. Pada pemodelan ini input port diisi oleh clock. Switch memiliki nilai threshold. Nilai threshold menjadi batas switch untuk on ke sisi input. Ketika nilai control port sudah mencapai nilai threshold, switch akan on ke sisi input port. Dengan demikian, rangkaian ini berfungsi untuk mengatur kapan nilai energy dapat mulai dihitung. Dibawah ini adalah gambar switch dan contoh pemilihan nilai threshold yang dalam penelitian ini berupa waktu.

\section{Blok Jaringan Saraf Tiruan}

Pada penelitian kali ini digunakan sebuah JST yaitu sebagai penentu nilai dari $\mathrm{R}$ arc. Input dari JST ini adalah jumlah 
serabut dan energy. Adapun metode yang digunakan adalah elman neural. Blok JST ini didapatkan menggunakan library matlab yang kemudian dilatih sesuai dengan parameterparameter yang telah ditentukan. Neural network yang digunakan adalah neural network dari masing-masing serabut. Adapun switch control menentukan neural network mana yang akan dieksekusi.

Seperti yang sudah diterangkan sebelumnya, input dari JST kali ini adalah jumlah serabut dan jumlah energi. Adapun outputnya adalah Rarc. Dalam rangkaian diatas, nilai S adalah reperesentasi dari jumlah serabut, nilai $\mathrm{E}$ adalah representasi dari jumlah energy dan nilai $\mathrm{R}$ adalah representasi dari nilai Rarc

\section{Komponen Pendukung}

Komponen pendukung disini memiliki peran untuk melengkapi rangkaian-rangkaian utama yang ada diatas. Dimulai dengan komponen solver configuration. Komponen ini adalah komponen fisikal yang harus ada dalam setiap rangkaian fisikal pada Simulink. Solver configuration berfungsi untuk menentukan banyaknya frekuensi sampling pada pemodelan. Karena dalam percobaan menggunakan frekuensi sampling 10.000/s. maka, pada sample time diinputkan nilai 0.0001. Kemudian ada komponen From \& GoTo. Komponen ini adalah komponen Simulink. From berfungsi untuk menerima sinyal dari GoTo yang memiliki label yang sama. GoTo mendapatkan masukan dari rangkaian yang ada dibelakangnya, adapun from memberikan masukan pada rangkaian yang ada didepannya. Simulink to Physical Signal Converter (S-PS) adalah sebuah komponen yang berfungsi untuk mengubah nilai simulink menjadi nilai fisikal. Sedangkan Physical to Simulink Converter (PS-S) adalah sebuah komponen yang berfungsi untuk mengubah nilai fisikal menjadi nilai Simulink. Kedua komponen ini digunakan dalam rangkaian pemodelan yang dapat berupa komponen fisikal maupun komponen Simulink sehingga dapat saling terhubung satu sama lain. Komponen display berfungsi untuk menampilkan nilai dari sebuah masukan dalam timesetep tertentu. Komponen scope berfungsi untuk menampilkan sebuah masukan dalam bentuk gambar. Dalam penelitian ini, scope digunakan untuk menampilkan bentuk gelombang dari tegangan sumber dan arus arcing yang sebelumnya terbaca oleh voltage sensor dan current sensor

\section{HASIL DAN PEMBAHASAN}

\section{A. Pelatihan Jaringan SarafTiruan (JST)}

Dalam melakukan pelatihan pada jaringan saraf tiruan dengan metode Elman Neural Network, telah disebutkan sebelumnya bahwa pembuatan perangkat JST menggunakan toolbox pada matlab.

\section{Parameter Pelatihan}

Seperti yang sudah disebutkan diatas, metode pelatihan TRAINLM adalah yang paling presisi, namun, hal ini perlu dibuktikan lebih lanjut. Maka dari itu, akan diuji berbagai macam metode pelatihan yang digunakan untuk memodelkan gelombang serabut 1. Parameter-parameter lainnya seperti jumlah hidden layer, jumlah neuron, dan lain-lain dibuat sama. Hasilnya adalah TRAINLM

\section{Jumlah Hidden Layer}

Sesuai dengan pernyataan sebelumnya, bahwa jumlah hidden layer dengan input lebih dari satu sebaiknya tidak lebih dari 2. Namun disini akan diuji berbagai jumlah hidden layer dengan parameter-parameter lainnya dibuat sama pula. Hasilnya adalah 2 hidden layer yang terbaik

\section{Jumlah Neuron}

Pengujian yang terakhir adalah dengan menentukan jumlah neuron. Jika mengikuti script neural network pada matlab, default dari neuron adalah 10 . Hasilnya adalah 20 neuron yang terbaik

4. Pembuatan Neural Network

Setelah berbagai percobaan diatas, diketahui parameterparameter terbaik dibanding dengan parameter lainnya. Dapat disimpulkan jenis-jenis parameter yang dipilih adalah:

Tabel 2. Parameter Pelatihan

\begin{tabular}{cccc}
\hline \hline Metode & Metode Train & $\begin{array}{c}\text { Jumlah Hidden } \\
\text { Layer }\end{array}$ & $\begin{array}{c}\text { Jumlah } \\
\text { Neuron }\end{array}$ \\
\hline Elman & TRAINLM & 2 & 20 \\
Backprop & & & \\
\hline \hline
\end{tabular}

\section{Penentuan Input \& Target Pelatihan}

Setelah arsitektur NN dibuat, kemudian yang dilakukan adalah menentukan input dan target pelatihan $\mathrm{NN}$ tersebut. dalam penelitian kali ini, input dari neural network ada dua, yakni serabut dan jumlah energy. Sedangkan targetnya adalah $\mathrm{R}$ arcing

\section{Memulai Pelatihan \& Monitoring}

Setelah input dan target pelatihan ditentukan, berikutnya adalah menentukan parameter-parameter pelatihan di dalam neural network yang telah dibuat. Contohnya adalah epochs (jumlah iterasi), target, dan lain-lain. Setelah parameter ditentukan, train dapat dimulai

\section{Hasil Pelatihan Neural Network}

Pelatihan neural network dalam percobaan ini menggunakan parameter yang terbaik hasil dari percobaan diatas. Metode pelatihan menggunakan trainlm, jumlah hidden layer 2 dan jumlah neuron 20. Dalam penelitian ini, serabut yang dilatih adalah serabut 1,3,6,12 dan 24.

\section{B. Hasil Pemodelan dengan Data Training}

Simulasi model dilakukan sebanyak lima kali, sebanyak serabut yang akan dimodelkan, yaitu serabut $1,3,6,12,24$. Data simulasi model tersebut kemudian dibandingkan dengan data percobaan yang digunakan untuk melakukan training JST menggunakan metode Mean Absolute Percentage Error, sehingga didapatkan tingkat akurasi dari masing-masing pemodelan. Arus arcing selesai menggunakan pengaturan switch off secara manual. 


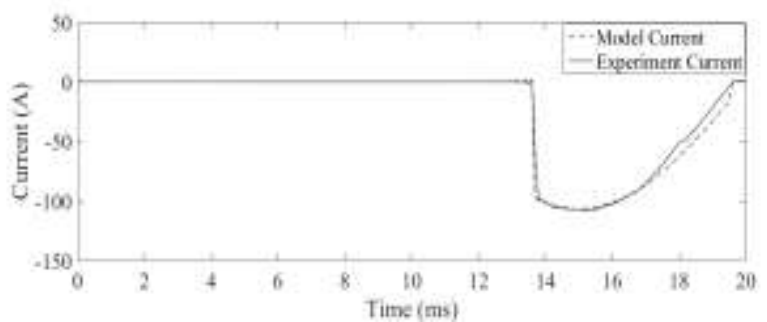

Gambar 5. Perbandingan Arus Pemodelan dan Percobaan (Data Training) Serabut 1

Tabel 3.

Eror Pemodelan

\begin{tabular}{|c|c|c|}
\hline Jumlah Serabut & $\begin{array}{c}\text { Jenis } \\
\text { Pemodelan } \\
\end{array}$ & MSE \\
\hline \multirow{3}{*}{ Serabut 1} & Tegangan & 58.72276883 \\
\hline & Arus & 16.65445803 \\
\hline & Hambatan & 49.93474312 \\
\hline \multirow{3}{*}{ Serabut 3} & Tegangan & 100.0965751 \\
\hline & Arus & 17.77324287 \\
\hline & Hambatan & 200.3116234 \\
\hline \multirow{3}{*}{ Serabut 6} & Tegangan & 201.8148888 \\
\hline & Arus & 143.9601619 \\
\hline & Hambatan & 31.36391 \\
\hline \multirow{3}{*}{ Serabut 12} & Tegangan & 318.5309863 \\
\hline & Arus & 46.71694074 \\
\hline & Hambatan & 4.440189086 \\
\hline \multirow{3}{*}{ Serabut 24} & Tegangan & 9627,118 \\
\hline & Arus & 1244,925 \\
\hline & Hambatan & 0,0093 \\
\hline
\end{tabular}

\section{Hasil Pemodelan dengan Data Non-Training}

Hasil pemodelan dengan data non-training maksudnya adalah menguji program menggunakan data yang berbeda dengan data yang digunakan untuk melakukan training JST. Arus arcing selesai menggunakan pengaturan switch off secara manual.

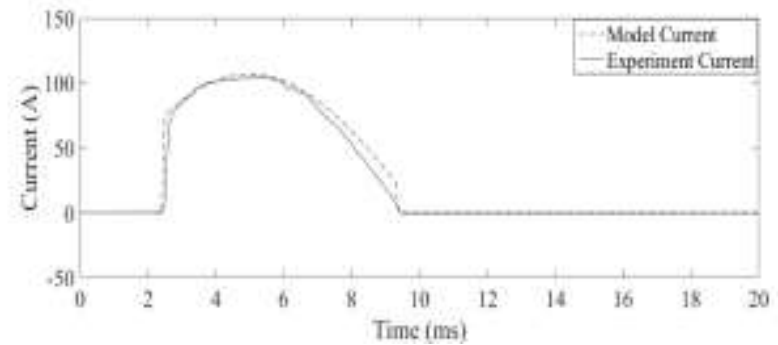

Gambar 6. Perbandingan Arus Pemodelan dan Percobaan (Data NonTraining) Serabut 1

\section{KESIMPULAN}

Dari Pemodelan arus arcing diatas, didapatkan nilai MSE dan untuk masing-masing serabut adalah:

Serabut 1: $\mathrm{MSE}=16.34543$

Serabut 3: $\mathrm{MSE}=16.24647$

Serabut 6: $\mathrm{MSE}=44.12924$

Serabut 12: $\mathrm{MSE}=21.32577$

Serabut 24: $\mathrm{MSE}=1244.925$

Durasi arcing cenderung meningkat seiring dengan bertambahnya jumlah serabut, namun dalam beberapa kasus terjadi sebaliknya. Adapun nilai arus puncak dari arcing cenderung sama.

Arc flash tegangan rendah tidak membahayakan bagi pengguna, namun jika arc flash terjadi dekat dengan bahan yang mudah terbakar dapat memicu terjadinya kebakaran.

\section{DAFTAR PUSTAKA}

[1] J. Maida, P.E., "Arc Flash Overview and Qualifications", Maida Engineering Inc, Fort Washington, 2009

[2] T. Gammon and J. Matthews, "The Historical Evolution of ArcingFault Models for Low-Voltage Systems", Industrial \& Commercial Power Systems Technical Conference, 1999 IEEE, pp. 1-6

[3] J. J. Lowke, "Simple Theory of Free-Buming Arcs," Journal of physics D: Applied Physics, vol. 12, 1979, pp. 1873-1886

[4] T. H. Lee, "Plasma physics and the interruption of an electric circuit," Proc. ofthe IEEX, vol. 57, Mar. 1969, pp. 307-323

[5] Albert M. Smoak, P.E., Adam J. Keeth, "An Investigation of Low Voltage Arc Flash Exposure”, IEEE 2013, pp. 184

[6] Albert M. Smoak, P.E., Adam J. Keeth, "An Investigation of Low Voltage Arc Flash Exposure", IEEE 2013, pp. 184

[7] C.T. Lin, and C.S.G. Lee, Neural fuzzy systems: A neuro-fuzzy synergism to intelligent systems. Upper Saddle River, NJ: PrenticeHall Inc., 1996

[8] L. Fausset, Fundamentals of neural networks: architectures, algorithms, and applications, New Jersey: Prentice-Hall, 1994

[9] O. R. Schurig, "Fault voltage drop and impedance at short-circuit currents in low-voltage circuits," AIEE Trans., vol. 60, 1941, pp. 479-487

[10] N. Sanjaya, "Pemodelan Busur Api (Arc Flash) Listrik Tegangan berbasis Jaringan Syaraf Tiruan (Artificial Neural Network)", Universitas Dian Nuswantoro, Semarang, 2015 